\title{
頸髄損傷者における単速度動作特性をもつ ジョイスティックの操作特性“
}

\section{井手將文**, 藤家 馨**, 御手洗謙二***, 黒須顕二****}

This report deals with cervical injuries who suffer from spasms and paralysis of extremities. Their ability to manipulate a computer screen pointing device was studied. The subjects attempted to aim the pointing device, a single-speed floating action joystick, so that the cursor overlapped the target provided on CRT display. Their ability was examined at eight cursor speed levels within two subject groups; eight cervical injuries and three abled persons.

The subject's total operating time was comprised of reaction time, approaching time to target, adjusting time near target with detailed behavior, and switching time. Similar operational time patterns for cursor speed were observed in both groups. At the adjusting operation on high speed level, inching operation were repeated. Inching operation times consisted of inching ON-time and OFF-time. The subject's ON-times converged near the controllable minimum. The ON-times of the cervical injury group were longer than those of abled person. OFF-times were longer than ON-times, with a positively skewed distribution. The OFF-time distribution was also wider for the cervical injury group.

本論文は，四肢麻盘を有する頸䯣損傷者におけるポインティングデバイス操作特性を明らかにする ことを目的とした. 使用したデバイスは単速度動作特性をもつジョイスティックであり, CRT 画面上 でのカーソルと目標との重ね合わせ実験を, 頸髄損傷者 8 名と健常者 3 名を対象に, 8 段階のカーソ ル速度で実施した. 1 回の試行における操作時間は, 操作開始までの反応時間, 目標まで一気に接近 する接近時間, 目標近傍で細かく重ね合わせる調整時間, 目標との重なりを確認して確定入力を行う スイッチング時間の 4 要素で構成され, 頸髄損傷者と健常者はカーソル速度に対し同様の時間パター ンを示した. 高速時の調整動作でインチング操作が繰り返された. インチングの ON 時間は, 各被験 者の操作下限近辺に集中し, 頸髄損傷者は健常者より長い時間となった. OFF 時間は全被験者におい て ON 時間より長く右裾広がりの分布となり, 頸髄損傷者ではより広い分布をもつ者が出現した。 (キーワード : ポインティングデバイス, 頸髄損傷者, ジョイスティック, インチング操作)

* 1994 年 1 月 24 日受付

*** 総合せき損センター 医用工学研究室 Dept. of Rehabilitation Eng. R \& D, Spinal Injuries Center.

*** 九州芸術工科大学 Kyushu Institute of Design.

**** 近畿大学 九州工学部 Faculty of Eng., Kinki Univ. in Kyushu.

\section{1. はじめに}

重度肢体不自由者にとって，コンピュータは社会参 加のために欠くことのできない道具となっている，市 販のアプリケーションソフトの多くは，キーボードお よびマウス操作で入力を行うが, 障害のためにキーボ ード操作を行えない人は, より操作可能なポインティ 
ングデバイスを利用し, CRT 上の文字盤で文字を選択 することでキーボード操作を可能とするエミュレータ を使用している．また，マウス操作を行えない人は， 他のポインティングデバイスを利用する場合も多く, 今後, さらにポインティングデバイスのニーズは増加 すると考えられる。

ポインティングデバイスは, CRT 上の点もしくは各 種メニューやアイコンなどの選択に利用されているが, 筋力低下や感覚麻痺を有し, 可動域制限や痙性を伴う ことの多い重度肢体不自由者では, 健常者と比べて, その操作能力は低下している. 肢体不自由者ではカー ソルの移動速度 (または移動感度), 操作力, 作業域な どの適応範囲は健常者に比べて限定されており, 障害 の程度が重度になればなるほど, その幅は狭くなるも のと考えられる。また，肢体不自由者に適したポイン ティングデバイスに必要な作動力, 移動速度 (感度), 形状は, 障害の種類および程度により異なり, 個人差 も大きい.

これまでの多くの研究により，マウスは健常者にと って最も有効なポインティングデバイスのひとつとさ れている ${ }^{123)}$ が, 肢体不自由者のポインティングデバ イス操作に関する研究は少ない. 井手 ${ }^{4)}$ は, 肢体不自由 者は, マウス, トラックボールなどの分解能が高く微 細な操作を必要とするポインティングデバイスよりも， 4 個の押ボタンを配置したステップキーや，ジョイス ティックのほうが容易に操作できると報告している.

一般に, 頸髄損傷者は運動麻瘏による上肢可動域制
限や操作力低下，および感覚麻痺による操作フィード バック感覚の減少などにより, その操作能力は低下し ているものと考えられている．肢体不自由者の障害程 度を一定の基準で分類化することは難しいが，頸骫有損 傷者ではその障害の特徵から, 麻痺筋および運動能力 が残存している筋の筋力を調べることで，同程度の残 存能力を有する者を分類することは比較的容易と考え られる．表 1 に総合せき損センターにおける頸骮有損傷 者の残存レベルの分類法を示す.

今回の報告では，4 個のマイクロスイッチを内蔵し た単速度動作特性をもつジョイスティックを操作対象 とし, カーソル移動速度に対する操作者の操作パター ン，および目標近傍におけるカーソルのインチング操 作に着目し，その特徴を明らかにする.

\section{2. ポインティングデバイス操作}

\section{2-1. 操作における 4 つの phase}

図 1 a に示すように, CRT 画面上の 2 つの枠 A, B において，ポインティングデバイスを用いて Aにある カーソルを B に移動させる場合, 最短経路である A と Bを結ぶ直線コースをとることはなく，目標近傍まで はおおまかな接近を行い，近傍でオーバーシュートや アンダーシュートの微細な動きを繰り返して目標に到 達する，時間軸上でのカーソルと目標点の距離の関係 を図 $1 \mathrm{~b}$ の模式図で示す.すなわち,

表 1 総合せき損センターにおける残存レベル分類法

Tab. 1 S.I.C. classification of remained level of cervical injury.

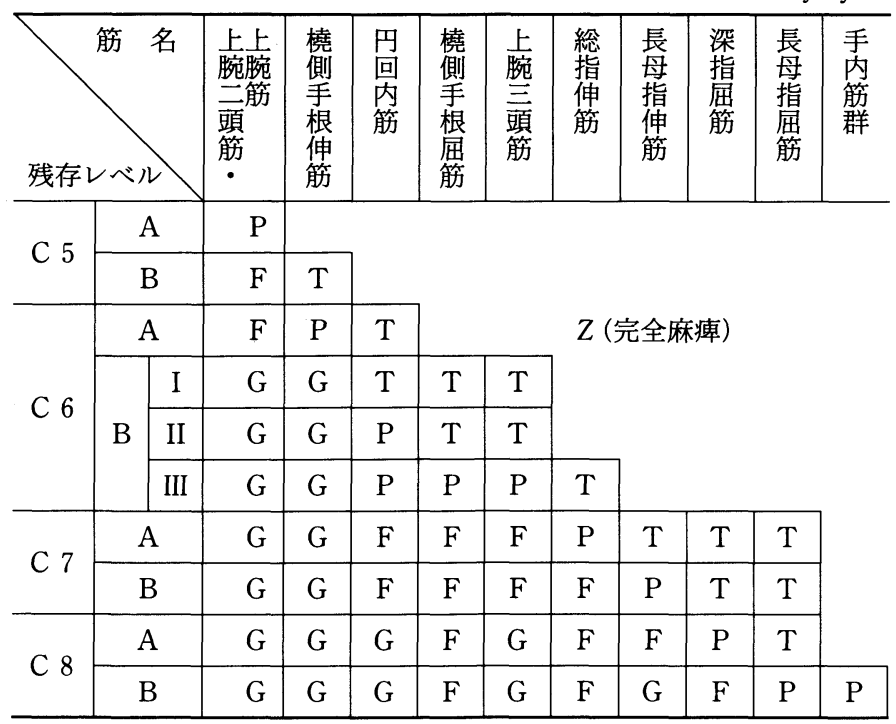

$\mathrm{G}$ ：優, F：良, P：可, $\mathrm{T}$ : 不可, $Z$ : 完全麻痺 


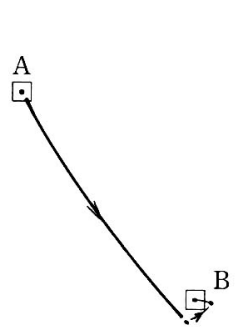

(a)

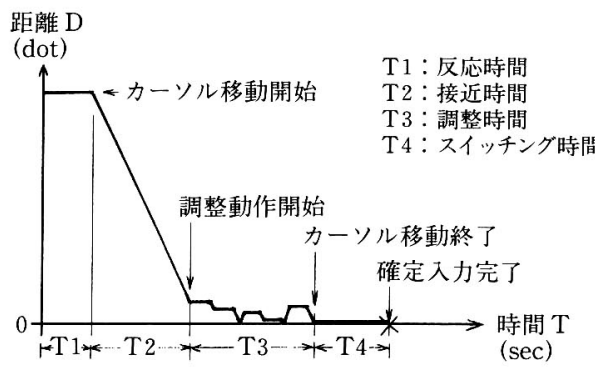

(b)

図 1 カーソルの移動経路 ( a ) とその際のカーソルから目標までの 距離と時間の関係 $(\mathrm{b})$

Fig. 1 Locus of cursor (a), and the relationship between distance and operating time (b).

・カーソルの移動方向を決め, ポインティングデバ イスを操作し始めるまでの反応時間（T 1)

・目標点の近傍まで一気に近づく接近時間（T 2)

・目標点の近傍で重ね合わせる調整時間（T 3)

・重ね合わせを確認してクリックなどのスイッチ操 作を行うスイッチング時間（T 4)

の段階を経て操作が完了することがわかる.

各時間における動作を, それぞれ反応動作，接近動 作, 調整動作, スイッチング動作とし, ジョイスティ ック操作時の作業にあてはめると次の 4 段階になる.

(1) 反応動作：課題の提示に対してどの方向にジョ イスティックを倒すかを判断し，その態勢をとる.

(2) 接近動作：カーソルを目標の方向に近づけるた めにジョイスティックを一気に倒し，その状態を 保持し, 目標と重なり合うと思われる時点で手を 離す。

（3） 調整動作：カーソルと日標との偏差や方向を確 認しながら,ジョイスティックの微細操作を繰り 返卞。

（4）スイッチング動作：重ね合わせを確認して確定 のスイッチ操作を行う.

また, 目標点近傍でのオーバーシュートについて考 えてみると, カーソルの移動速度が大きくなれば，そ の量も増大して頻回な調整動作が必要となり. 調整時 間（T 3）にも大きく影響を与えるものと考えられる.

\section{2-2. インチング操作}

CRT 画面上での目標点近傍での操作戦略は, 近傍で はいちど操作を中止してカーソルを停止させ, カーソ ルと目標点の距離（偏差）とカーソル速度（制御量の 速度）に応じて操作量と方向を判断し，瞬間的な操作 を繰り返す離散的な操作（インチング操作）を行うと 考えられる。これらの動作は目標の提示により事前に
制御量を決めて操作を行うものであり, 前項の調整動 作ではインチング操作を間歇的に繰り返し，結果とし て重ね合わせを図っていると考えられる．今回の実験 ではカーソルの移動速度が大きくなればインチング操 作が多数出現すると考えられる．また，インチング操 作におけるインチング $\mathrm{ON}$ 時間 $\left(\mathrm{T}_{\mathrm{i}}\right)$ は瞬時で, ON 操 作と ON 操作の間にインチング $\mathrm{OFF}$ 時間 $\left(\mathrm{T}_{\mathrm{v}}\right)$ が出 現する。

\section{3. 実 験}

実験では, CRT 画面に指定された 2 点間でカーソル を移動させ，その移動経路および経過時間をデー夕と して収録，分析を行った。

\section{3-1. 実験方法}

ディスプレイを被験者の正面に配置し，操作方法の 説明を行った後に，操作についての理解を深めるため 練習を行った. ジョイスティックについては頸䯣損傷 者の使用を考慮し, 図 2 に示すようなイボ付丸型, $\mathrm{T}$ 型, U 型の 3 種のノブを準備し, 練習の段階で最適な ものを選択してジョイスティックに取りつけた。また，

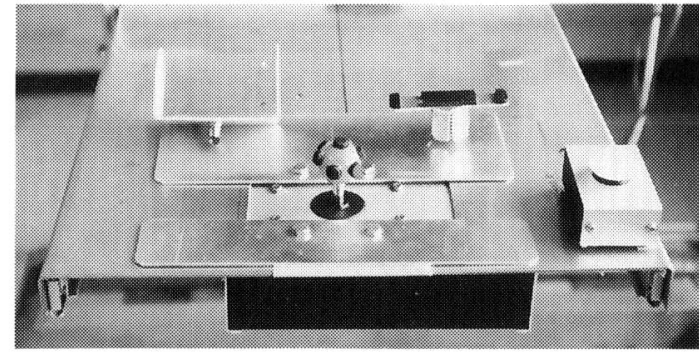

図 2 ノブの形状 (U型, 丸型, $\mathrm{T}$ 型)

Fig. 2 Knobs (U-type, Ball-type, T-type). 


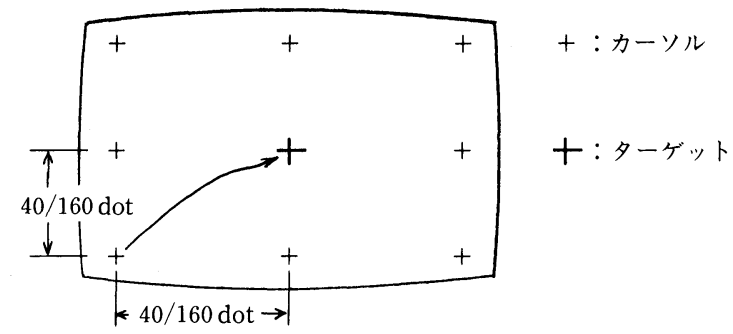

図 3 カーソルのスタート位置

Fig. 3 Starting position of cursor on a CRT.

ジョイスティックおよびスイッチング用押しボタンは， 被験者の操作しやすい位置に配置した。

実験では, 図 3 に示すように CRT 画面中央に $1 \mathrm{dot}$ 幅のラインで描かれた十字のターゲットを表示し，ビ ープ音と同時にターゲットから上下左右および斜め 4 方向のいずれかにランダムにカーソルが出現し, ジョ イスティックを用いてカーソルを中央のターゲットに できるだけ早く重ね合わせ，スイッチング用押しボタ ンを押すことにより操作完了とした.

カーソルの出現点の位置はカーソルの移動速度によ り 2 段階に分け, $4,8,12,16 \mathrm{dot} / \mathrm{sec}$ の場合は夕ーゲ ットからタテ $40 \mathrm{dot}, \exists コ 40 \operatorname{dot}$ の距離, $20,40,60,80$ $\mathrm{dot} / \mathrm{sec}$ の場合は夕ーゲットからタテ $160 \mathrm{dot}, \exists コ$ $160 \operatorname{dot}$ の距離である.また, 各速度におけるカーソル 出現回数は，上下左右および斜め 4 方向の各々 2 回ず つ計 16 回である.すべてのカーソル速度における反 応, 接近, 調整, スイッチングの各時間について分析 を行うとともに, 被験者全員にインチング操作が顕著 に現れたカーソル速度 $80 \mathrm{dot} / \mathrm{sec}$ の場合のデータに ついて，インチング特性に関する分析を行った。

各時間分析では接近動作から調整動作への切換時点 をどのような基準で判断するかが，検討を要するポイ ントと考えられる. 吉田ら ${ }^{6)}$ はマウス操作におけるこ の切換時点を加速度波形の第 3 ピークとし, 藤本ら ${ }^{7)}$ は加速度波形の第 3 ゼロ点としているが, 今回のジョ イスティックではカーソルは一定速度で移動し, カー ソル位置を入力時間によりコントロールするために, これらの基準を適用することはできない.今回の実験 では, 接近動作時に目標点近傍 $10 \operatorname{dot} の$ 範囲を通過す ることが示されたので, $10 \mathrm{dot}$ 近傍まで近づいた時点 で, それ以後に移動が停止した時点を調整動作開始時 点と考えた。

\section{3-2. 計測機器システム}

実験の計測システムを図 4 に示す。パソコン (NEC PC 9801 VM 2) のマウスインタフェースに, ジョイス ティック/マウス信号変換器ジョイマウス (システムテ



図 4 計測システム構成図

Fig. 4 Diagram of measuring system.

クニカ製）を接続し，それにジョイスティックおよび 押しボタン SS 24 (サン電業製) を接続した。ジョイス ティックはマイクロスイッチ 4 個で構成された上下左 右および斜め 4 方向への 2 值化特性をもつポインティ ングデバイスである.レバー長は $40 \mathrm{~mm}$, 先端のノブ はネジ込み式になっており, 前述の丸型, T型, U 型 のノブを簡単に交換でき，丸型ノブ装着時の作動力は $300 \mathrm{~g}$ である.スイッチング用の押しボタンの作動力 は $120 \mathrm{~g}$ であり，頸髄損傷者にも押しやすいようにボ タン径を $30 \mathrm{~mm}$ にした.

\section{3-3. 被験者}

被験者は上肢に障害をもつ頸髄損傷者 8 名および健 常者 3 名である. 被験者の身体的特徵と使用したノブ の種類を表 2 に示す。なお，今回の被験者である頸髄 損傷者は，損傷した頸髄より下部の神経支配域のすべ

表 2 被験者の身体的特徵および操作ノブの形状

Tab. 2 Personal character of subjects and knobs.

\begin{tabular}{|c|c|c|c|c|c|}
\hline No. & 年齢 & 性別 & $\begin{array}{c}\text { 残存レベル分類 } \\
\text { (操作手) }\end{array}$ & $\begin{array}{l}\text { 当院入院後 } \\
\text { の経過年月 }\end{array}$ & $\begin{array}{l}\text { ノブ } \\
\text { 形状 }\end{array}$ \\
\hline 1 & 18 & M & $\mathrm{C} 5 \mathrm{~A}$ & 2 年 5 力月 & 丸型 \\
\hline 2 & 18 & M & $\mathrm{C} 5 \mathrm{~A}$ & 1 年 4 力月 & $\mathrm{U}$ 型 \\
\hline 3 & 20 & M & $\mathrm{C} 6 \mathrm{~A}$ & 8 力月 & $\mathrm{T}$ 型 \\
\hline 4 & 23 & M & C 6 B II & 4 力月 & U型 \\
\hline 5 & 29 & M & C 6 B II & 1 年 6 力月 & U型 \\
\hline 6 & 20 & M & C 6 B III & 1 年 4 力月 & 丸型 \\
\hline 7 & 23 & M & C 6 B III & 3 力月 & $\mathrm{T}$ 型 \\
\hline 8 & 21 & M & C 7 B & 5 年 8 力月 & $\mathrm{T}$ 型 \\
\hline 9 & 34 & F & 健常者 & - & 丸型 \\
\hline 10 & 40 & M & 健常者 & - & 丸型 \\
\hline 11 & 35 & M & 健常者 & - & 丸型 \\
\hline
\end{tabular}


てに運動および感覚麻摩を伴うため，どの支配域から 下が麻痖しているかという残存レベルにより障害の程 度を表現する. 被験者の残存レベルは Zancolli の分類 法5)を参照して, 総合せき損センターにおいて作成し た分類法（表 1 ）を用いて判定した。操作手の残存レ ベル C 5 A が 2 名, C 6 A が 1 名, C 6 B II が 2 名, C 6 B IIIが 2 名, C 7 B が 1 名である.C 5 A C 6 A の 3 名 は, 上腕二頭筋や上腕筋の働きにより肘届曲は可能で あるが, 上腕三頭筋は麻痺しており自力での肘伸展は 不可能である. また, 手関節の自力での運動も不可能 である. C 6 B IIの 2 名は, 肘伸展は不可能であるが, 手関節の自力での運動は背屈が可能であり, 手関節の 固定が可能となっている. C 6 B III〜C 7 B の 3 名は, 时伸展も可能であり, C 7 B の被験者は手関節の掌屈 が可能で, 不完全ながら指の運動も可能である.

\section{4. 結 果}

\section{4-1. 各種操作時間}

操作時間を, 反応時間 $\mathrm{T} 1$, 接近時間 $\mathrm{T} 2$, 調整時間 T 3, スイッチング時間 T 4 に分けて分析した. 分析は カーソル速度に対する各操作時間のパターンをみると ともに, 頸髄損傷者, 健常者両群の平均值の差を異分 散 $\mathrm{t}$ 検定により検定した.

（1）反応時間 T 1

図 5 に示されるように, 反応時間は両グループとも に速度には無関係にほぼ一定で, 全実験を通した T 1 の平均値および標準偏差は, 頸髄損傷者グループ $0.81 \pm 0.41 \mathrm{sec}$, 健常者グループ $0.54 \pm 0.13 \mathrm{sec} て ゙$, 頸 髄損傷者グループが健常者グループに比べて長い時間 を必要としていた（有意水準： $\alpha=0.01 ）$.

\section{（2）接近時間 $\mathrm{T} 2$}

図 6 に示されるように，両グループともにカーソル 移動速度に反比例した值を示しており，カーソル移動 速度の増加に対して T 2 が減少することがわかる. 両 グループ間で T 2 に差異があるとはいえなかった $(\alpha=0.01)$.

\section{（3） 調整時間 T 3}

図 7 に示されるように, 両グループともにカーソル 移動速度の増加に対応して T 3 が増加しているが, 健 常者グループと比較して, 頸髄損傷者グループが大き くなっていた $(\alpha=0.01)$. 健常者グループの速度 80 $\mathrm{dot} / \mathrm{sec}$ 時の平均調整時間は, 頸髄損傷者グループの 速度 20〜 $40 \mathrm{dot} / \mathrm{sec}$ 間の值を示していた。

（4） スイッチング時間 T 4

図 8 に示されるように, T 4 は両グループともに速

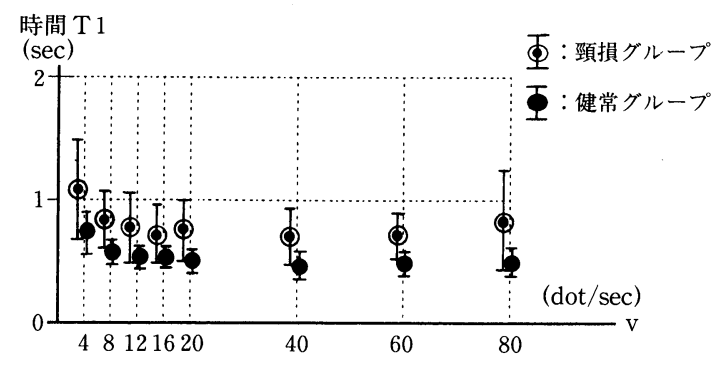

図 5 グループ別の反応時間( T 1)の平均および標準偏差

Fig. 5 Means and SD of response time T1 on two groups.

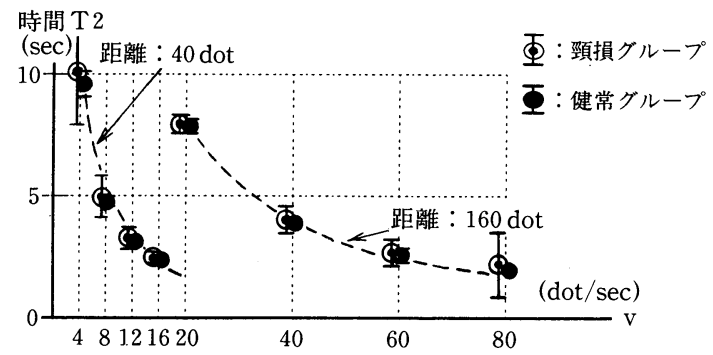

図 6 グループ別の接近時間(T 2)の平均および標準偏差

Fig. 6 Means and SD of approaching time T2 on two groups.

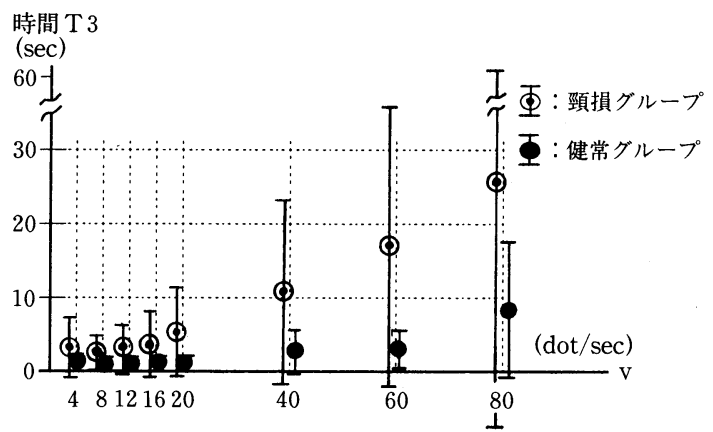

図 7 グループ別の調整時間(T 3)の平均および標準偏差

Fig. 7 Means and SD of adjusting time T3 on two groups.



図 8 グループ別のスイッチング時間(T 4)の平均および 標準偏差

Fig. 8 Means and SD of switching time T4 on two groups. 


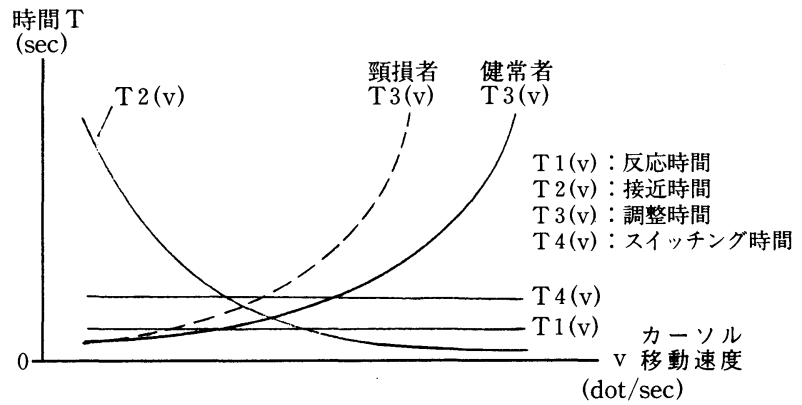

図 9 カーソル移動速度と各操作時間

Fig. 9 Relationship between cursor speed and each operating times.

度には無関係にほほ一定で, 全実験を通した T 4 の平 均值および標準偏差は頸髄損傷者グループ1.07士 $0.36 \mathrm{sec}$, 健常者グループ $0.39 \pm 0.14 \mathrm{sec} て ゙$, 頸髄損傷 者グループが健常者グループに比べて長い時間を必要 としていた $(\alpha=0.01)$.

\section{(5) 全操作時間}

図 $5 \sim 8$ をまとめて図 9 に模式図で示す. T 1, T 2, $\mathrm{T} 3$, T 4 の総和が全操作時間であり, その值が最小に なるカーソル速度が最適速度となる。 T 3 の曲線の増 加の割合が健常者より大きい頸䯑道損傷者グループでは, 最適速度が健常者より遅くなることがわかる.

\section{4-2. インチング操作特性}

すべての被験者において，調整動作時に頻回のイン チング操作が出現したカーソル速度 $80 \mathrm{dot} / \mathrm{sec}$ 時の, 被験者ごとのインチング $\mathrm{ON}$ 時間 $\mathrm{T}_{1}$ の度数分布, 平 均, 標準偏差, 累積度数, 歪度, 尖度を図 10 に, イン チング $\mathrm{OFF}$ 時間 $\mathrm{T}_{\mathrm{v}}$ の度数分布，平均，標準偏差，最 頻値, 最高值, 最低值を図 11 に示す。

\section{(1) インチング操作の出現回数}

各被験者におけるインチング操作の出現回数は ON, $\mathrm{OFF}$ 操作とも同数であり, 図 10 の累積度数で示され る. 試行 16 回の合計で $120 \sim 472$ 回の範囲であった。 頸髄損傷者 8 名の累積度数平均および標準偏差は $337.8 \pm 73.6$ 回であった.健常者 3 名では $173.7 \pm 84.4$ 回と少ない傾向を示したが, 最も累積度数の多い健常 者より少ない，あるいはほほ同等の值を示した頸䯣損 傷者もいた。

\section{（2）インチング $\mathbf{~} \mathbf{N}$ 時間 $\mathbf{T}_{1}$}

図 10 に示されるように, 各頸髄損傷者の $\mathrm{T}_{1}$ 平均値 は 97〜166 ms, 健常者の $T_{1}$ 平均値は 54 60 ms で, 頸 髄損傷者は健常者に比べ素早い操作ができない傾向を 示した。


一夕を計数して各度数としている．度数分布表からみ
ると, 最頻値の近くに平均值をもつ正規分布に近い形 を示しているが， $\mathrm{T}_{1}$ の度数分布の分布型は, 尖度と歪 度による正規性の検定結果では，全被験者において正 規分布から有意に偏っていた。

（3）インチング OFF 時間 $\mathbf{T}_{\mathrm{v}}$

図 11 に示されるように, 右裾に長く広がる分布であ

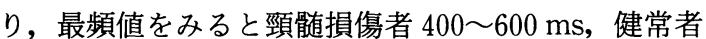

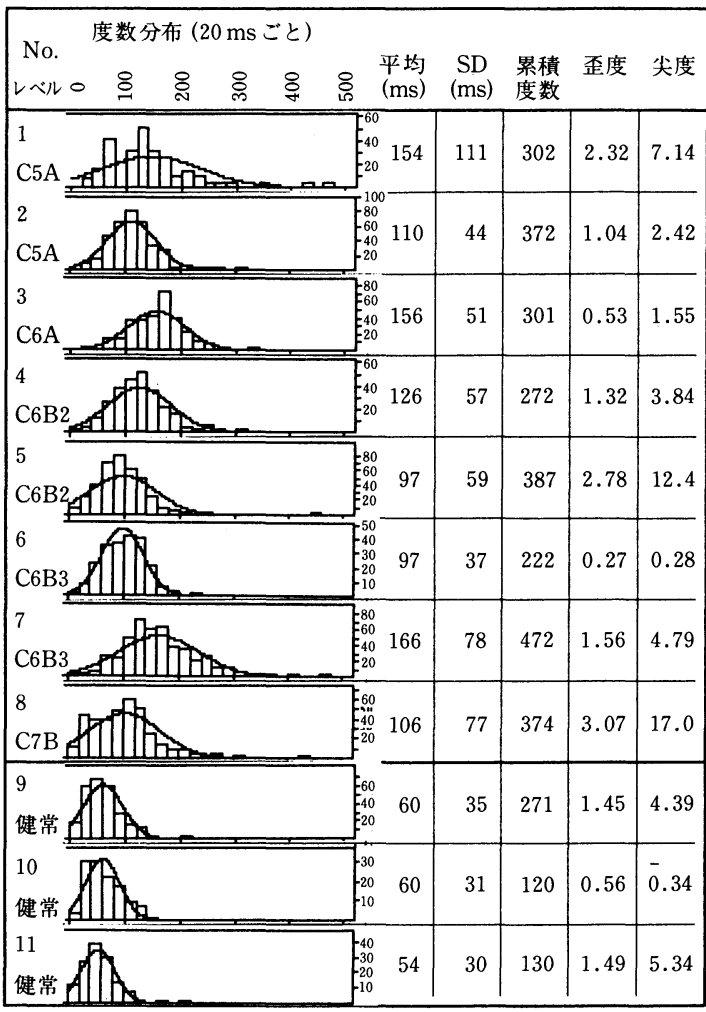

図 10 インチング $\mathrm{ON}$ 時間 $\left(\mathrm{T}_{1}\right)$ の度数分布, 累積度 数, 歪度, 尖度

Fig. 10 Histogram, frequency, skewness and kurtosis of inching-ON time $\mathrm{T}_{1}$. 
400 500 ms を示しており，両者の明確な違いはなか った。また広がりの指標として標準偏差值をみると， 頸髄損傷者 240 $2380 \mathrm{~ms}$, 健常者 210 460 ms を示し ており，頸髄損傷者で大きな個人差を示した。

\section{5. 考 察}

Card ら $^{1)}$ は, ポインティングデバイスの特性比較の なかで, 操作時間がターゲットまでの距離とターゲッ トの大きさに関連するとした Fittsの式を引用し， マ ウス, ジョイスティック, ステップキー, テキストキ 一のうち，マウスがよい成績を示しているとした。ま た, 村田 ${ }^{3)}$ は同様に, マウス, ジョイスティック, トラ ックボール, ジョイカード, ライトペン, タッチスク リーンの各ポインティングデバイスに対して Fitts の 式を引用し，心理評価なども加えた特性比較を行った。 しかしながら,これらの比較評価ではカーソルの移動 速度（または移動感度）についての検討は行われてい ない. カーソルの移動速度（または移動感度）が高い

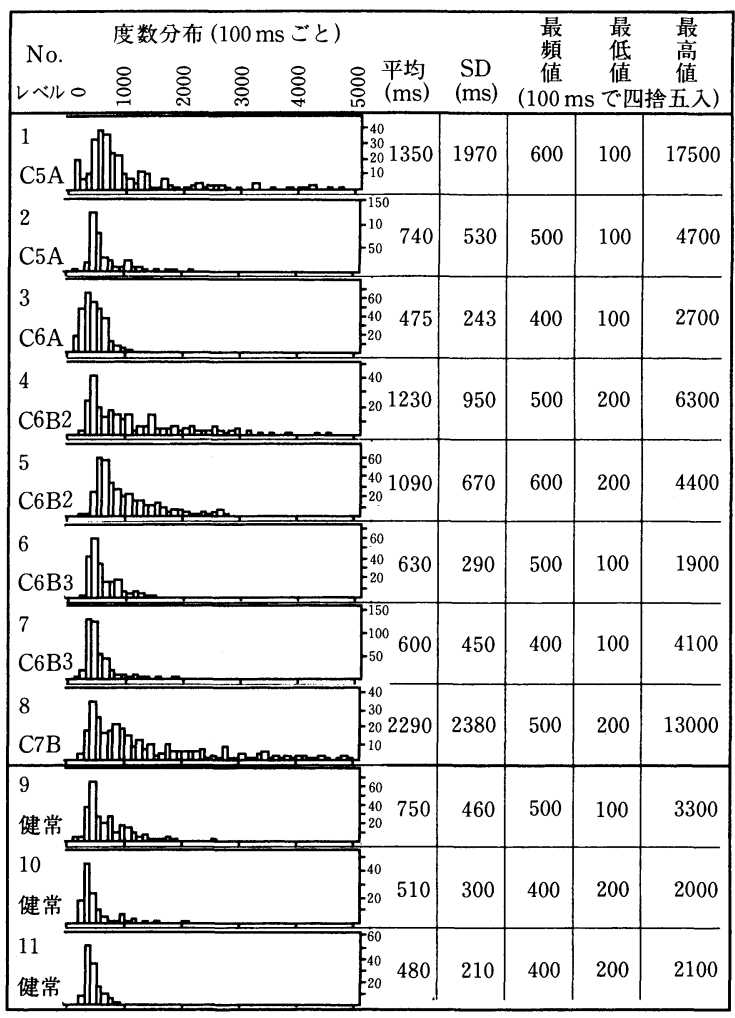

図 11 インチング $\mathrm{OFF}$ 時間 $\left(\mathrm{T}_{\mathrm{v}}\right)$ の度数分布, 最頻 值, 最低値, 最高值

Fig. 11 Histogram, mode, minimum and maximum of inching-OFF time $T_{v}$.
場合には，特に操作時間に大きく影響を与えると考え られる。

健常者における手動制御特性については多くの研究 がなされているが, 大山秀, 池田ら ${ }^{9)}$ の入力操作具に着 目した操作量と表示量の比 (Control-Display Ratio： $\mathrm{CD}$ 值)についての最適值の考察では, 各入力操作具に それぞれ $\mathrm{CD}$ 值の最適値があることを示している。 ま た西田ら ${ }^{10)}$ は, 健常者の微細位置決め作業においては Fitts の式が適用できず， CD 值が操作時間に影響を及 ぼすことを示している．CD 值は今回の実験における カーソル移動速度と反比例する值と考えられるが, 今 回の操作時間の分析でも，これら 3 報告と同様の結果 を示している.

\section{5-1. 操作に要する各時間}

今回の実験における操作時間は 4 つの phase に分 かれており, 図 9 に示したように各々の時間はカーソ ル移動速度の関数として表現され，この総和時間を最 小とする速度值があることを示した。

各操作時間のグラフからも明らかなように，カーソ ル移動速度について両グループの值に差はあるものの, 同様の操作パターンを示している.すなわち, T 1, T 4 は移動速度に対し一定で, T 2 は反比例, T 3 は指数的 増加傾向を示している．以下に各時間における両グル ープの差異について考察する。

\section{（1）反応時間}

反応時間には, (1)カーソルの出現を発見し, (2)カー ソルの移動方向を判断し, (3)上肢操作の方法を考え, (4)上肢を動かし入力を開始するまでの時間が含まれる. (1) (3)の時間は潜時であり, 頸髄損傷者と健常者とに 変わりはなく, 頸䯑損傷者と健常者の反応時間の差は (4)の時間の差と考えられる.これは, 残存筋群を使っ た操作に加えて, 頸髄損傷者がポインティングデバイ スを操作しようとするときに, 操作前に体幹のバラン スを保持する動作を必要としたり, 操作する方向によ ってはジョイスティックの握り方や手指を添える位置 が異なり,これに時間を要したためと考えられる.

\section{(2) 接近時間}

頸髄損傷者はジョイスティックをいちど傾けて保持 してしまえば，その状態を保つことは容易だと考えら れ, 健常者との差もほとんど生じることはない. 保持 がうまくいかない場合は持ち替え動作が必要となり, その時間が付加される.

\section{（3） 調整時間}

調整時間には後述のインチング操作の出現が影響す る.インチング ON 操作は, そのほとんどが瞬時の操 作であり, 使用する筋群の差異により瞬時操作の困難 
な頸髄損傷者は，健常者より重ね合わせが困難となる。 また, インチング OFF 操作は, オーバーシュートなど で方向が反転するときに持ち替え動作や体幹バランス の調整動作が入るため, 健常者と大きな時間差が生じ る場合が多いと考えられる.

\section{(4) スイッチング時間}

今回はスイッチングの方法として大型押しボタン操 作としたが, 被験者 1 ～ 3 では手関節の固定装具を使 用していることもあり, 上肢からの>ィードバックが 不十分で誤操作が生じやすく, 目視によるフィードバ ックを必要としていた，そのため，重ね合わせを完了 した時点で誤操作しないように目視しながら手をボ夕 ンまで移動させており，時間を必要としている。被験 者 5〜 7では, 体幹固定のために常時片手で車いすを 保持しており, 残る片手でジョイスティックと押しボ タンを操作せねばならず，ジョイスティックから押し ボタンへと手を移動する時間を必要としている.

\section{5-2. インチング操作}

\section{（1）インチング $\mathrm{ON}$ 時間 $\mathrm{T}_{1}$}

健常者のインチング操作については, 行待 ${ }^{11)}$ は, CD 值が小さくなる（今回の実験では移動速度の増大にあ たる）につれて制御形態は ON 状態持続時間制御から OFF 状態持続時間制御に変化し,このような制御では ON 持続時間が最短になるように制御を行い，その時 間は手掌の内・外旋所要時間と同じであると報告して いる. 今回の実験の $80 \mathrm{dot} / \mathrm{sec}$ 時の調整動作は, 行待 の報告でいう OFF 状態持続時間制御の状況と考えら れ， $\mathrm{T}_{1}$ の度数分布（図 10）も被験者ごとに操作可能な 最短の時間で制御していることを示している.

$\mathrm{T}_{1}$ の度数分布は, 健常者に比べて頸髄損傷者のほう が大きい傾向がうかがえるが, その原因は, 健常者が 手関節の動きを利用して操作を行うのに対し, 手関節

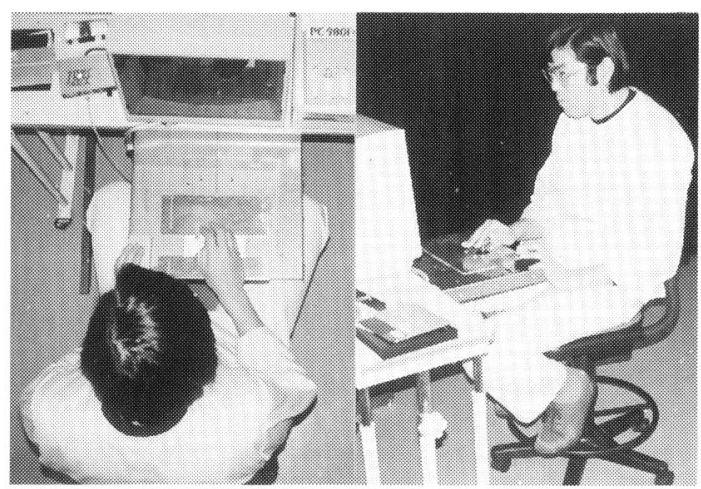

図 12 健常者によるジョイスティック操作例

Fig. 12 Joystick control example by abled person.
麻痺を有する頸葡損傷者では肘や体幹の動きを利用し て操作することによると考えられる．両者の操作時の 写真を図 12,13 に示すが，健常者は操作手の手根関節 掌側をテーブルに置き，これを支点として手指の動き を利用していたのに対し，頸髄損傷者は肘をはり前腕 全体を浮かして操作していた。

各被験者の $\mathrm{T}_{1}$ の平均値は 54 〜 $166 \mathrm{~ms}$ であったが, この值は操作者の身体能力ばかりでなく, ポインティ ングデバイス自体の構造にも関連している。ジョイス ティックレバーが倒された後に復元するための時間は, レバーの戻りバネの強さにより変化すると考えられる. また，ジョイスティックが ON 状態となった後のレバ 一の行きすぎ代も $T_{1}$ に影響を与えると考えられる. その意味で，戻りバネを強くしたり行きすぎ代を小さ くすることにより，より短い $\mathrm{T}_{1}$ での操作が可能とな り，操作性は高くなるものと考えられる.

（2）インチング $\mathrm{OFF}$ 時間 $\mathbf{T}_{\mathrm{v}}$

$\mathrm{T}_{\mathrm{v}}$ の度数分布 (図 11) では被験者全員が右裾広がり の分布を示していたが，右裾は長時間のインチング OFF 操作の出現を意味している. 健常者の $\mathrm{T}_{\mathrm{v}}$ の最高 值は 2000 3000 ms 程度であり, 頻度もわずかであ る.このときの動作は, ターゲットとカーソルがきち んと重なり合っているかどうかを，操作をやめて画面 上を注視し，確認していると考えられる。

頸髄損傷者における $T_{\mathrm{v}}$ の右裾への幅広い分布につ いては，健常者と同様に画面上を注視するほかに，頸 髄損傷者に特有の動作が観察される。健常者は上肢か らの感覚フィードバックにより, 把持状態やスティッ クを押しているかどうか, どちらの方向に倒している かなどを, ジョイスティックを見ることなく知ること ができる，一方，頸髄損傷者では上肢からの感覚フィ ードバックが十分でないために，操作を繰り返すとき にジョイスティックとディスプレイの間で視線を移動

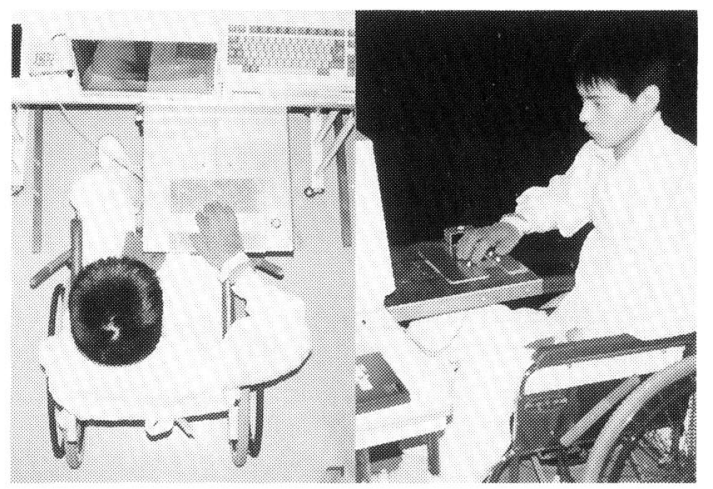

図 13 頸髄損傷者によるジョイスティック操作例

Fig. 13 Joystick control example by spinal injury. 
させ, 視覚で手元を確認して操作する動作が観祭され る.

また, 頸髄損傷者では被験者 1,8 に代表されるよう な, きわめて長い時間の $\mathrm{T}_{\mathrm{v}}$ が出現しているが, これら は姿勢を矯正したり，腕を少し休めたりする動作によ るものである，腹筋や背筋の麻痺により体幹のバラン スがわるいことや，上肢筋力が十分でないことが影響 していると考えられる. 視線の移動, 姿勢の矯正, 作 業途中での腕を休めるなどの動作は, 頸髄損傷者の操 作において当然出現する動作であり, インチング操作 時における頸髄損傷者の操作特性のひとつとして考え るべきである.また, これらの動作の出現は必ずしも 障害の程度によるものだけではない，これらの原因と しては, 入院後の期間が短く, 身体機能が全体として まだ十分でなかったり, 過去にテレビゲームの操作経 験がなく, 実験に先立つ操作練習では操作スキルが十 分に上達できなかったことなどが考えられる。

次に, $\mathrm{T}_{\mathrm{v}}$ の最頻值については頸髄損傷者と健常者 で同程度の値を示しているが, このことは頸䯣損傷者 においても健常者と同様に, 手元に視線を移さずに画 面だけを見てインチング操作を繰り返す操作があるこ とを示していると考えられる.

全実験結果より, カーソル接近時には高速度で移動 し, 調整時, すなわちインチング操作時には低速度と なる速度パターン特性をもつポインティングデバイス が，より効率的な操作を可能とすると考えられる. 本 実験で使用したジョイスティックでこれを実現するた めには, 単速度動作特性ではなく, 2 段階速度特性など 速度を変化させる特性をもたせることが考えられる。 ただし, 肢体不自由者ごとに適切な速度切換のタイミ ングは異なり, 各々が操作可能なインチング ON 時間 が速度切換タイミングの指標になると考えられる。

\section{6. おわりに}

頸䯚有損傷者のポインティングデバイス操作特性をみ るため, 単速度動作特性のジョイスティックを操作対 象とし, カーソル移動速度の観点から, その操作特性 に対するアプローチを行った．操作特性を評価するた めに反応時間, 接近時間, 調整時間, スイッチング時 間を測定するとともに，調整時の特徴的な動作である インチング操作について, インチング ON 時間および OFF 時間に着目して分析した。

インチング ON 時間では, 頸髄損傷者が健常者より
大きい值を示す傾向にあり，この原因としては，健常 者が手関節部を支点として手関節の動きで操作するの に対し, 頸髄損傷者では肩を支点とした腕全体の動き や体幹の動きで操作することによるものと考えられた。

インチング $\mathrm{OFF}$ 時間では，その度数分布において 著しく右裾広がりとなる頸髄損傷者がいたが，この原 因としては，画面とポインティングデバイス間の視線 の移動動作，姿勢矯正動作，腕を休める動作などによ るものと考えられた。

\section{参考文献}

1) S. K. Card, et al. : Evaluation of mouse, ratecontrolled isometric joystick, step keys and textkeys for text selection on a CRT, Ergonomics, 21(8), 601 613, 1978.

2) 広瀬通孝：ポインティング作業の評価, SICE 関西支部シンポジウム計測・制御におけるマンマ シンインタフェース講演論文集，47～52，1984.

3）村田厚生：刘話型システムにおけるポインティ ング装置の操作性に関する実験的検討, 人間工学, 28(3), 107〜117, 1992.

4）井手将文ほか：上肢障害者におけるポインティ ングデバイスの操作特性, 第 1 回ヒューマン・イ ンタフェース・シンポジウム論文集, $371 \sim 376$, 1985.

5) E. Zancolli : Clinical Orthopeadics and Rerated Resarch, No. 112, 104, 1975.

6）吉田 剛ほか：マウス操作に関する基礎研究, 第 2 回ヒューマン・インタフェース・シンポジウ ム論文集, 71〜 74, 1986.

7）藤本晶子ほか：手/足マウスによるポインティ ング動作の制御特性と自己負担感覚のモデル, Human Interface News \& Report, 2(3), 267 274, 1987.

8）大山 毅：手動追值制御における操作具の C/ $\mathrm{D}$ 比の研究, 日本人間工学会第 20 回大会講演集, 240 241, 1979.

9) 池田義弘ほか：2 変数手動制御系と操作機器に ついて, 日本人間工学会第 22 回大会講演集, 230 231, 1981.

10）西田修三ほか：人間の遠隔操作による微細位置 決め作業, 人間工学, $27(4), 181 〜 189,1991$.

11）行待武生ほか：インチング操作による手動制御 の研究, 人間工学, $25(1), 1 \sim 9,1989$. 